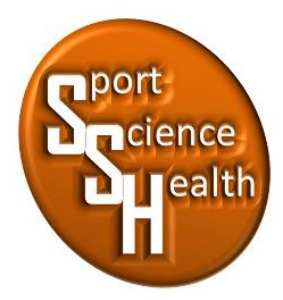

ISSN 2715-3886

\title{
Hubungan Aktivitas Fisik dan Pola Makan Terhadap Status Obesitas Pada Siswa Sekolah Menengah Pertama
}

\author{
Yuliana $^{1 \star}$, Mashuri Eko Winarno ${ }^{2}$ \\ 1,2Jurusan Pendidikan Jasmani Kesehatan dan Rekreasi, Fakultas IImu Keolahragaan, \\ Universitas Negeri Malang, Jalan Semarang No. 5, Malang, Jawa Timur, 65145, Indonesia \\ *Penulis koresponden: Yuliananyingnying24@gmail.com, 085649902912
}

\begin{abstract}
The purpose of this study was to determine the relationship of physical activity and eating patterns on obesitystatus using the correlational method. The population is 55 students and the sample size is 40 students. Based on the results of the analysis it can be concluded that; 1 ) there is a relationship between physical activity and obesity of male students $r_{\text {table }} 0,381<r_{\text {count }} 0,462,2$ ) there is a relationship between eating patterns and obesity of rable male students $0,381<r_{\text {count }} 0,430,3$ ) there is a significant relationship between physical activity and diet with the obesity status of male students sig.F Change value of $0.004<0.05$ and $R$ value of $0.607,4$ ) there is no relationship between physical activity and obesity status of female students $r_{\text {table }} 0.553>r_{\text {count }} 0.364$, 5 ) there is no relations hip between eating patterns with obesity status of female students, $r_{\text {table }} 0.553>r_{\text {count }} 0.389$, 6) there is no significant relations hip between physical activity and eating patterns with obesitystatus of female students sig.F Change value of $0.177>0.05$ and $R$ value of 0.541 .
\end{abstract}

Keyword: physical activity; dietary habit; obesitystatus

\begin{abstract}
Abstrak: Tujuan penelitian untuk mengetahui hubungan aktivitas fisik dan pola makan terhadap status obesitas dengan menggunakan metode korelasional. Jumlah populasi adalah 55 siswa dan jumlah sampel adalah 40 siswa. Berdasarkan hasil analisis dapat disimpulkan bahwa; 1) ada hubungan antara aktivitas fisik dengan obesitas siswa laki-laki $r_{\text {tabel }} 0,381<r_{\text {hitung }} 0,462,2$ ) ada hubungan antara pola makan dengan obesitas siswalakilaki $r_{\text {tabel }} 0,381<r_{\text {hitung }} 0,430,3$ ) ada hubungan yang signifikan antara aktivitas fisik dan pola makan dengan status obesitas siswa laki-laki nilai sig.F Change $0,004<0,05$ dan nilai $R 0,607,4)$ tidak ada hubungan antara aktivitas fisik dengan status obesitas siswa perempuan $\left.r_{\text {tabel }} 0,553>r_{\text {hitung }} 0,364,5\right)$ tidak ada hubungan antara polamakan dengan status obesitas sis wa perempuan, $r_{\text {tabel }} 0,553>r_{\text {hitung }} 0,389,6$ ) tidak ada hubungan yang signifikan antara aktivitas fisik dan pola makan dengan status obesitas siswa perem puan nilai sig.F Change 0,177>0,05dannilai R 0,541 .
\end{abstract}

Kata kunci: aktivitas fisik; pola makan;status obesitas

\section{PENDAHULUAN}

Masalah obesitas di Indonesia masih memasuki persentase besar bagi anak berusia 5-12 tahun yaitu sebesar $18,8 \%$ dengan kategori obesitas yaitu sebesar 8,8\% dan kategori gemuk sebesar 10,8\%, sedangkan pada prevalensi kurus mencapai angka sebesar $11,2 \%$ dengan kategori kurus sebesar $7,2 \%$ dan kategori sangat kurus sebesar $4,0 \%$ hal tersebut juga terjadi pada anak berusia 5-12 tahun. Berdasarkan data statistik 
menunjukkan bahwa prevalensi obesitas di Indonesia lebih besar daripada prevalensi kurus pada anak usia 5-12 tahun di Indonesia (Riset Kesehatan Republik Indonesia, 2013). Sedangkan di provinsi Sulawesi Selatan terdapat kasus obesitas berada pada urutan ketujuh dari sepuluh jenis penyakit dan terbanyak di provinsi Sulawesi Selatan yaitu total kasus sebanyak 2.671 (Dinas Kesehatan Republik Indonesia, 2013). Pola makan yang tidak baik atau tidak memenuhi gizi seimbang dan serat yang tidak terpenuhi seperti sayur dan buah, seringnya kegiatan yang tidak bermanfaat contohnya merokok serta aktivitas yang dilakukan kurang seperti olahraga merupakan faktor perilaku dan resiko utama dalam penyebab obesitas.

Dari hasil penelitian anak laki-laki mempunyai resiko obesitas lebih besar dibanding perempuan, hal tersebut kemungkinan karena anak perempuan lebih membatasi makanan untuk memperoleh penampilan yang baik.Pada usia remaja antara 12-15 tahun konsumsi makanan jajanan dan aktivitas fisik ringan dapat beresiko obesitas dimana masing-masing terjadi hingga 3,2 kali dan 5,1 kali (Pramono, 2014). Kurangnya aktivitas fisik yang dilakukan adalah faktor paling utama yang dapat mempengaruhi kelebihan berat badan atau obesitas, kebiasaan aktivitas fisik dalam keseharian pada anak ini juga termasuk dalam kegiatan olahraga ringan contohnya berjalan kaki ataupun bersepeda. Porsi olahraga ringan pada anak yang tidak rutin dalam melakukannya dalam keseharian adalah 39,4\% dari kegiatan normal (Ayu \& Sartika, 2011). Pada zaman modern ini jarang ditemui orang-orang yang melakukan aktivitas fisik setiap hari karena banyaknya alat trasportasi yang mudah ditemui dan pastinya canggih seperti lift, mobil, motor maupun escalator dan alat transportasi lainnya. Untuk pergi ke suatu tempat, anak-anak maupuan masyarakat tidak perlu repot untuk jalan kaki dan efektif dan efisien saat melakukan perjalanan jauh karena kecanggihan alat transportasi yang dimiliki di zaman modern ini hal ini merupakan penyebab kurangnya aktivitas yang dilakukan masyarakat setiap hari (Rumajar, 2015). Pada standarisasi fisik ideal dapat dilihat dari beberapa perspektif yaitu perspektif budaya dan perspektif kesehatan, dilihat dari segi budaya tubuh dapat di katakan ideal apabila padat, berisi, mempunyai wajah tampan dan enak dipandang, memiliki wajah seperti bayi, sedang dalam segi kesehatan standar fisik yang ideal mempunyai IMT < 27,0 (Hikmawati \& Mas'ud, 2015).

Dari observasi dan wawancara yang dilakukan peneliti sebagian besar orangtua dari anak yang mempunyai berat badan berlebih sama-sama bekerja dengan jam kerja pagi hingga sore, terdapat beberapa siswa yang mempunyai ibu dan bekerja di Luar Negeri untuk mencari nafkah, terdapat juga siswa yang hanya mempunyai ayah dan bekerja dari pagi hingga petang. Dari penjelasan tersebut maka dapat disimpulkan bahwa segala macam aktivitas termasuk aktivitas fisik dan pola makan anak tidak terkontrol dengan baik karena kurangnya perhatian dan arahan dari orangtua yang sibuk mencari nafkah untuk keluarga, sebagian besar siswa makan makanan yang siap saji seperti mie instan, roti ataupun yang lain-lain. Aktivitas fisik juga kurang terkontrol karena kurangnya arahan dari orangtua maka anak bebas melakukan hal yang mereka senangi tanpa adanya aturan main game terutama game online dimana game ini bisa dilakukan dengan duduk di tempat tanpa melakukan aktivitas fisik bahkan jam tidur mereka terganggu karena kurangnya pengaturan aktivitas yang dilakukan oleh anak, maka anak akan mudah mengalami obesitas karena asupan nutrisi yang masuk tidak seimbang dengan kebutuhan energi yang dikeluarkan (Beck \& Sales, 2001).

Khomsan menjelaskan bahwa seorang yang mengalami obesitas cenderung lebih peka pada rasa dan bau makanan yang merupakan faktor eksternal daripada terhadap rasa lapar atau yang disebut faktor internal, jadi seseorang yang mengalami obesitas memiliki rasa ingin makan ketika ada makanan yang tersaji dihadapannya (Sofa, 2018). Berdasarkan penjelasan di atas maka peneliti menentukan subyek yang akan diteliti adalah anak pada usia sekolah menengah pertama dikarenakan untuk penelitian terdahulu yangmeneliti tentang hubungan aktivitas fisik dengan status obesitas pada anak usia sekolah menengah pertama di daerah Malang masih kurang. Dengan demikian perlu dilakukan penelitian tentang hubungan aktivitas fisik dan pola makan dengan kejadian obesitas pada anak usia Sekolah Menegah Pertama.

Menurut Sari bahwa terdapat 5 Faktor yang mempengaruhi obesitas seorang anak yang berusia 2-20 tahun yaitu pada ranah konseling, frekuensi makanan, jumlah asupan makanan, aktivitas fisik, perilaku dan aspek emosi. Aspek yang dianjurkan tetap pada orientasi orangtua yaitu pada aspek makanan hingga aspek emosional (E. Sari, 2013), berdasarkan pernyataan di atas maka hipotesis pada penelitian ini adalah adanya hubungan aktivitas fisik dan pola makan terhadap status gizi pada siswa Sekolah Menengah Pertama yang diuji dengan menggunakan uji Hipotesis. 


\section{METODE}

Penelitian ini menggunakan rancangan berbentuk diskriptif kuantitatif, jenis penelitian ini adalah penelitian korelasional. Variabel pada penelitian ini yaitu aktivitas fisik, pola makan dan status obesitas akan dinilai dan diukur pada satu waktu atau bersamaan dan kemudian melakukan analisis data yang dikumpulkan digunakan untuk menguji hipotesis. Populasi penelitian ini adalah siswa kelas VII yang mempunyai berat badan berlebih dan mengalami obesitas di SMPN 2 Bantur yang berjumlah 55 siswa. Pengambilan sampel menggunakan purposive cluster random sampling dengan populasi sebanyak 55 siswa, lalu dipilih siswa yang paling memenuhi kriteria, jadi sampel yang diambil adalah 40 siswa.

Instrumen penelitian yang digunakan yaitu: (1) pengukuran antropometri dilakukan dengan mengukur berat badan dan tinggi badan. Berat badan dan tinggi badan siswa akan diukur dengan menggunakan rumus Indeks Massa Tubuh (IMT), setelah itu maka peneliti menentukan kriteria dari setiap siswa. Dengan menggunakan acuan norma dari IMT per umur. Obesitas adalah data yang IMT $\geq 23,0$ bagi perempuan dan IMT $\geq 25,0$ bagi laki-laki, (2) pengukuran aktivitas fisik menggunakan Physical Activity Quesionaire for Children (PAQ-C) yaitu recall dengan aktivitas fisik yang dilakukan siswa pada 7 hari terakhir terdiri dari 10 butir dan jumlah dari butir soal menjadi standar nilai penentu kategori dari kuesioner, (3) pengukuran pola makan dengan menggunakan kuesioner. Dari hasil responden maka nilai dari setiap butir soal dijumlah dan jumlah dari setiap butir soal menjadi standar nilai penentu kategori dari kuesioner.

Pengumpulan data pada aktivitas fisik dan pola makan diperoleh dari hasil pengisian angket sedangkan pada obesitas dihasilkan dari pengukuran berat badan dan tinggi badan siswa yaitu dengan menggunakan rumus IMT.

HASIL

\section{Karakteristk Responden}

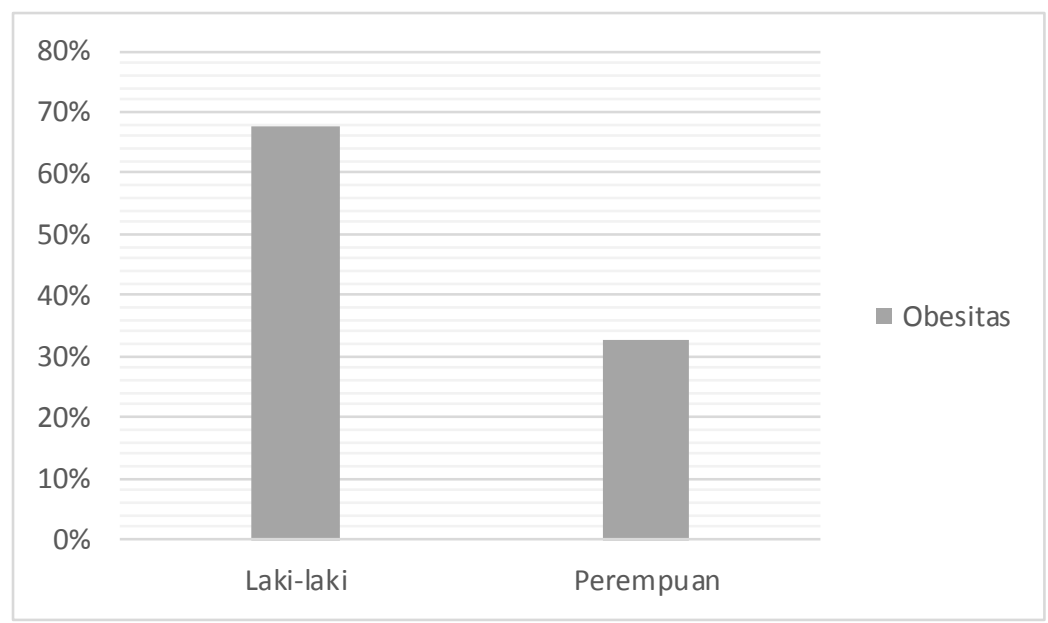

Gambar 1. Data Karakteristik Responden 
Distribusi frekuensi aktivitas fisik

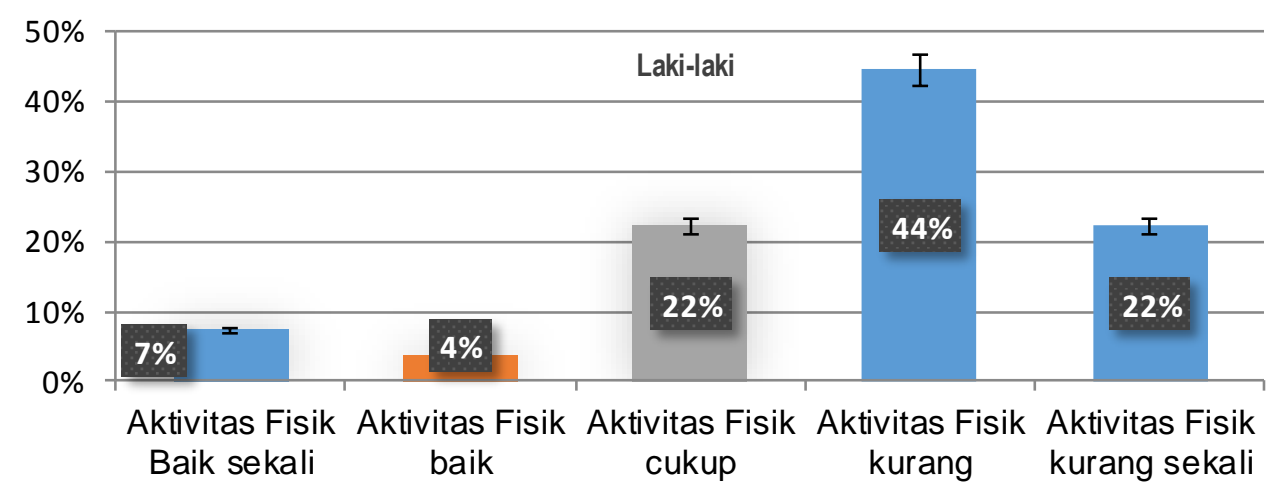

Gambar 2. Distribusi Frekuensi Aktivitas Fisik Laki-Laki

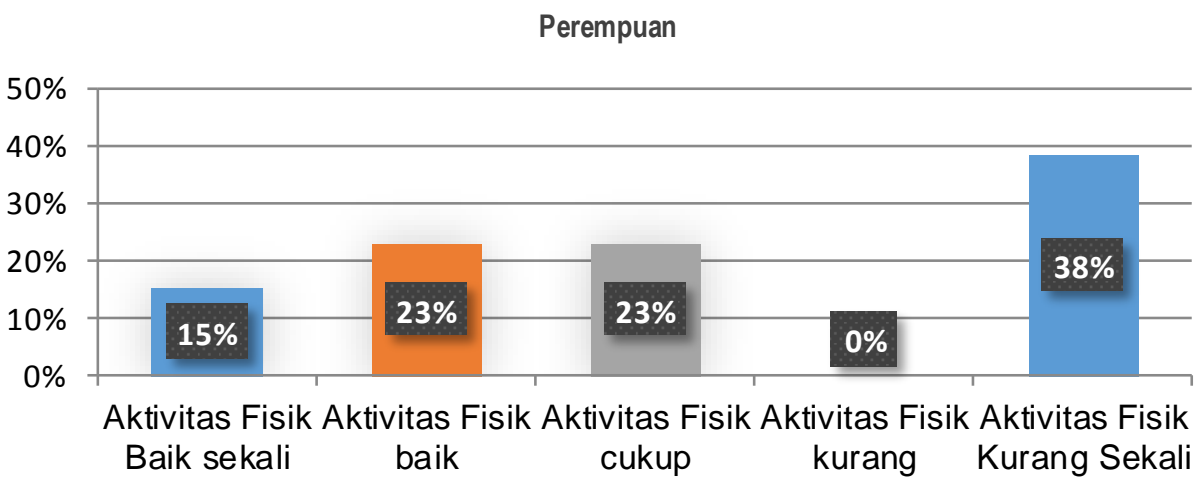

Gambar 3. Distribusi Frekuensi Aktivitas Fisik Perempuan

\section{Distribusi frekuensi pola makan}

Laki-laki

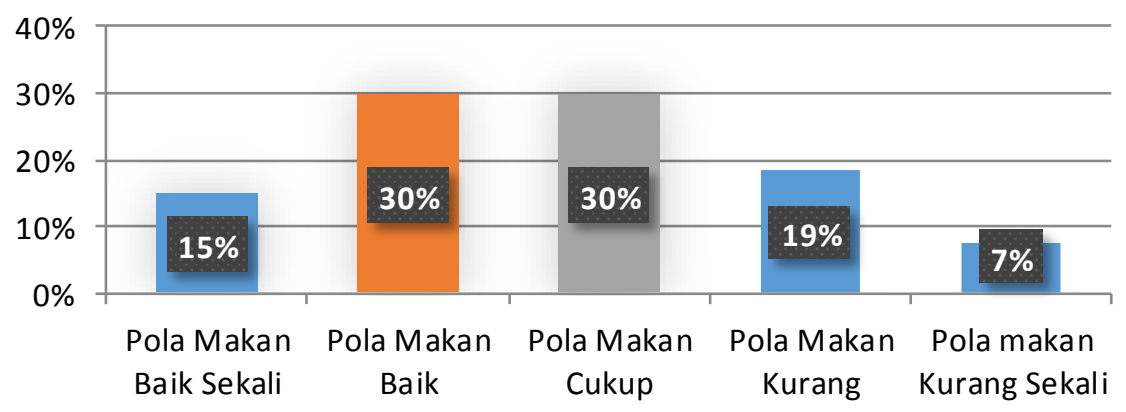

Gambar 4. Distribusi Frekuensi Pola Makan Laki-Laki

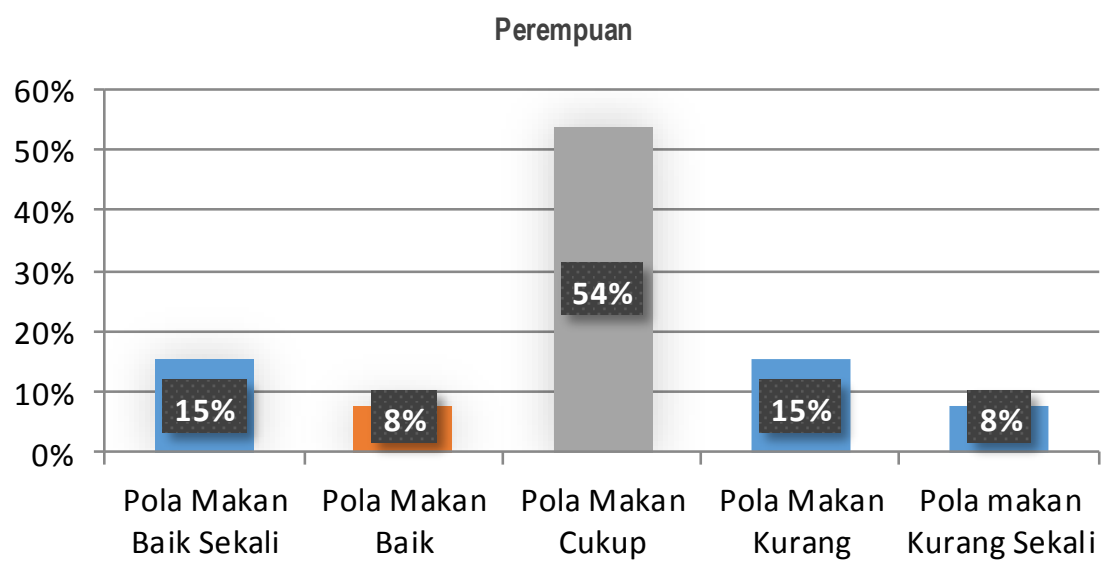

Gambar 5. Distribusi Frekuensi Pola Makan Perempuan 


\section{Uji Normalitas}

Tabel 1. Uji Normalitas Aktivias Fisik, Pola Makan dan Status Obesitas Siswa SMPN 2 Bantur

\begin{tabular}{cccc}
\hline Variabel & Nilai Signifikansi (D) & $\boldsymbol{\alpha}=\mathbf{0 , 0 5}$ & Keterangan \\
\hline$Y$ & 0,200 & $\alpha=0,05$ & $P>\alpha$ (data normal) \\
$X_{1}$ & 0,200 & $\alpha=0,05$ & $P>\alpha$ (data normal) \\
$X_{2}$ & 0,114 & $\alpha=0,05$ & $P>\alpha$ (data normal) \\
\hline
\end{tabular}

Berdasarkan perhitungan di SPSS dengan menggunakan uji Kolmogorov-Smirnov Test disimpulkan bahwa data status obesitas, aktivitas fisik dan pola makan berdistribusi normal, maka persyaratan normalitas untuk melanjutkan ke uji statistik selanjutnya terpenuhi.

\section{Uji Linieritas}

Tabel 2. Uji Linieritas Aktivias Fisik, Pola Makan dan Status Obesitas Siswa SMPN 2 Bantur

\begin{tabular}{ccccc}
\hline Variabel & $\mathbf{F}_{\text {hitung }}$ & Nilai Signifikansi & $\boldsymbol{\alpha}=\mathbf{0 , 0 5}$ & Keterangan \\
\hline$X_{1} Y$ & 0,663 & 0,804 & $\alpha=0,05$ & $P>\alpha=0,05$ (regresi linier) \\
$X_{2} Y$ & 0,460 & 0,928 & $\alpha=0,05$ & $P>\alpha=0,05$ (regresi linier) \\
\hline
\end{tabular}

Berdasarkan dari uji statistik SPSS dengan menggunakan Uji Anova dapat disimpulkan bahwa adja hubungan yang linier antara aktivitas fisik dengan status obesitas, ada hubungan yang linier antara pola makan dengan status obesitas.

\section{Uji Homogenitas}

\section{Laki-laki}

Tabel 3. Uji Homogenitas Aktivias Fisik, Pola Makan dan Status Obesitas Siswa SMPN 2 Bantur

\begin{tabular}{cccc}
\hline Variabel & Fhitung & Ftabel & Keterangan \\
\hline$X_{1} Y$ & 3,86 & 3,422 & Fhitung $>$ Ftabel (data tidak homogen) \\
$X_{2} Y$ & 4,63 & 3,422 & Fhitung $>$ Ftabel (data tidak homogen) \\
\hline
\end{tabular}

Berdasarkan dari uji perhitungan statistik dengan menggunakan Uji $\mathrm{F}$ dapat disimpulkan bahwa data antara aktivitas fisik dengan status obesitas dan antara aktivitas fisik dengan status obesitas adalah Homogen.

Perempuan

Tabel 4. Uji Homogenitas Aktivias Fisik, Pola Makan dan Status Obesitas Siswa SMPN 2 Bantur

\begin{tabular}{cccc}
\hline Variabel & Fhitung & F tabel & Keterangan \\
\hline$X_{1} Y$ & 4,54 & 4,256 & Fhitung $>$ Ftabel (data tidak homogen) \\
$X_{2} Y$ & 5,09 & 4,256 & Fhitung $>$ Ftabel (data tidak homogen) \\
\hline
\end{tabular}

Berdasarkan dari uji perhitungan statistik menggunakan Uji $F$ dapat disimpulkan bahwa data antara aktivitas fisik dengan status obesitas dan antara aktivitas fisik dengan status adalah Homogen.

\section{Uji Korelasi}

\section{Hubungan Aktivitas Fisik dan Pola Makan dengan Status obesitas Siswa Laki-Laki}

Tabel 5. Data Hubungan Aktivitas Fisik dan Pola Makan dengan Status obesitas Siswa Laki-laki

\begin{tabular}{cccc}
\hline Variabel & $\mathbf{r}_{\text {hitung }}$ & Nilai Signifikansi & Keterangan \\
\hline $\mathrm{X}_{1} \mathrm{Y}$ & 0,462 & 0,015 & $\mathrm{P}<\alpha=0,05$ (berhubungan) \\
$\mathrm{X}_{2} \mathrm{Y}$ & 0,430 & 0,025 & $\mathrm{P}<\alpha=0,05$ (berhubungan) \\
\hline
\end{tabular}

Dari hasil uji statistik di SPSS dengan menggunakan pearson correlation menunjukkan ada hubungan hubungan yang signifikan antara aktivitas fisik dengan status obesitas dan ada hubungan yang signifikan antara pola makan dengan status obesitas. 


\section{Hubungan Aktivitas Fisik dan Pola Makan dengan Status obesitas Siswa Perempuan}

Tabel 6. Data Hubungan Aktivitas Fisik dan Pola Makan dengan Status obesitas Siswa Perempuan

\begin{tabular}{cccc}
\hline Variabel & rhitung & Nilai Signifikansi & Keterangan \\
\hline$X_{1} Y$ & 0,364 & 0,222 & $P>\alpha=0,05$ (tidak berhubungan) \\
$X_{2} Y$ & 0,389 & 0,189 & $P>\alpha=0,05$ (tidak berhubungan) \\
\hline
\end{tabular}

Dari hasil uji statistik di SPSS dengan menggunakan pearson correlation menunjukkan tidak ada hubungan hubungan yang signifikan antara aktivitas fisik dengan status obesitas dan tidak ada hubungan yang signifikan antara pola makan dengan status obesitas.

\section{Uji Korelasi Berganda}

\section{Hubungan Aktivitas Fisik dan Pola Makan Terhadap Status obesitas Siswa SMPN 2 Bantur Kabupaten Malang}

Tabel 7. Data Hubungan Aktivitas Fisik dan Pola Makan Terhadap Status SMPN 2 Bantur Kabupaten Malang

\begin{tabular}{cccccc}
\hline L/P & Variabel & R Square & $\mathbf{R}$ & $\begin{array}{c}\text { Nilai } \\
\text { Signifikansi }\end{array}$ & Keterangan \\
\hline $\mathrm{L}$ & $\mathrm{X}_{1} \mathrm{X}_{2} \mathrm{Y}$ & 0,369 & 0,607 & 0,004 & (Ada hubungan) \\
$\mathrm{P}$ & $\mathrm{X}_{1} \mathrm{X}_{2} \mathrm{Y}$ & 0,293 & 0,541 & 0.177 & (Tidak ada hubungan) \\
\hline
\end{tabular}

Ket:

L: Laki-Laki

P: Perempuan

Dari hasil uji statistik di SPSS dengan menggunakan Korelasi Berganda menunjukkan ada hubungan antara aktivitas fisik dan pola makan dengan status obesitas dan menunjukkan tidak ada hubungan yang signifikan antara aktivitas fisik dan pola makan dengan status obesitas.

\section{Uji Hipotesis}

\section{Laki-Laki}

Tabel 8. Uji Hipotesis Aktivias Fisik, Pola Makan dan Status Obesitas Siswa SMPN 2 Bantur

\begin{tabular}{cccc}
\hline Variabel & thitung & Nilai Signifikansi & Keterangan \\
\hline$X_{1} Y$ & 2,645 & 0,014 & $P>a=0,05$ (ada hubungan) \\
$X_{2} Y$ & 2,428 & 0,023 & $P>\alpha=0,05$ (ada hubungan) \\
\hline
\end{tabular}

Berdasarkan uji statistik yang telah dilakukan dengan menggunakan SPSS menggunakan uji Regresi Linier dapat disimpulkan bahwa ada hubungan antara aktivitas fisik dengan status obesitas siswa laki-laki kelas VII SMPN 2 Bantur Kabupaten Malang dan pola makan dengan status obesitas pada siswa laki-laki kelas VII SMPN 2 Bantur Kabupaten Malang.

Tabel 9. Uji Hipotesis Aktivias Fisik dan Pola Makan Terhadap Status Obesitas Siswa SMPN 2 Bantur

\begin{tabular}{cccc}
\hline Variabel & F $_{\text {hitung }}$ & Nilai Signifikansi $\mathbf{F}$ & Keterangan \\
\hline$X_{1} X_{2} Y$ & 7,003 & 0,004 & $p<\alpha=0,05$ (ada hubungan) \\
\hline
\end{tabular}

Uji Hipotesis tiga variabel menggunakan analisis Regresi Linier Berganda. Dari data analisis statistika dengan menggunakan SPSS dapat disimpulkan bahwa ada hubungan antara aktivitas fisik dan pola makan terhadap status obesitas pada siswa laki-laki kelas VII SMPN 2 Bantur Kabupaten Malang. 


\section{Sumbangan Efektif dan Sumbangan Relatif}

Tabel 10. Sumbangan Efektif dan Sumbangan Relatif Aktivias Fisik, Pola Makan dan Status Obesitas

\begin{tabular}{ccccc}
\multicolumn{5}{c}{ Siswa SMPN 2 Bantur } \\
\hline No & Variabel & SE & SR & R Square \\
\hline 1 & $\mathrm{X}_{1} \mathrm{Y}$ & $19,8 \%$ & $0,998 \%$ & 0,369 \\
2 & $\mathrm{X}_{2} \mathrm{Y}$ & $16,98 \%$ & & \\
& Total & $36,86 \%$ & & \\
\hline
\end{tabular}

Ket:

SE: Sumbangan Efektif

SR: Sumbangan Realtif

Sumbangan Efektif paling besar adalah aktivitas fisik terhadap status obesitas.

\section{Perempuan}

Tabel 11. Uji Hipotesis Aktivias Fisik, Pola Makan dan Status Obesitas Siswa SMPN 2 Bantur

\begin{tabular}{cccc}
\hline Variabel & thitung & Nilai Signifikansi & Keterangan \\
\hline$X_{1} Y$ & 1,413 & 0,188 & $P>\alpha=0,05$ (tidak ada hubungan) \\
$X_{2} Y$ & 1,506 & 0,163 & $P>\alpha=0,05$ (tidak ada hubungan) \\
\hline
\end{tabular}

Berdasarkan uji statistik yang telah dilakukan dengan menggunakan SPSS menggunakan uji Regresi Linier dapat disimpulkan bahwa tidak ada hubungan antara aktivitas fisik dengan status obesitas pada siswa perempuan kelas VII SMPN 2 Bantur Kabupaten Malang dan tidak ada hubungan antara pola makan dengan status obesitas pada siswa perempuan kelas VII SMPN 2 Bantur Kabupaten Malang.

Tabel 12. Uji Hipotesis Aktivias Fisik, Pola Makan dan Status Obesitas Siswa SMPN 2 Bantur

\begin{tabular}{cccc}
\hline No & Variabel & Nilai Signifikansi & Keterangan \\
\hline 1 & $X_{1} X_{2} Y$ & 0,177 & $p>0,05$ (tidak ada hubungan) \\
\hline
\end{tabular}

Uji Hipotesis tiga variabel menggunakan analisis Regresi Linier Berganda dapat disimpulkan bahwa tidak ada hubungan antara aktivitas fisik dan pola makan terhadap status obesitas pada siswa perempuan kelas VII SMPN 2 Bantur Kabupaten Malang.

\section{Sumbangan Efektif dan Sumbangan Realtif}

Tabel 13. Sumbangan Efektif dan Sumbangan Relatif Aktivias Fisik, Pola Makan dan Status Obesitas Siswa SMPN 2 Bantur

\begin{tabular}{ccccc}
\hline No & Variabel & SE & SR & R Square \\
\hline 1 & $\mathrm{X}_{1} \mathrm{Y}$ & $13,69 \%$ & $0,999 \%$ & 0,293 \\
2 & $\mathrm{X}_{2} \mathrm{Y}$ & $15,6 \%$ & & \\
& Total & $29,29 \%$ & & \\
\hline
\end{tabular}

Sumbangan Efektif paling besar adalah pola makan terhadap status obesitas.

\section{PEMBAHASAN}

\section{Hubungan Aktivitas Fisik Dengan Status Obesitas Siswa Laki-Laki Kelas VII SMPN 2 Bantur Kabupaten Malang}

Dari hasil uji statistik di SPSS dengan menggunakan pearson correlation didapat rabel 0,381 dan rhitung 0,462 dimana rhitung lebih besar dibandingkan dengan rtabel, dengan taraf signifikansi yaitu $0,015(p<0,05)$ ini menunjukkan ada hubungan yang signifikan antara aktivitas fisik dengan status obesitas. Berdasarkan hasil penelitian Danari menunjukkan bahwa responden yang memiliki obesitas mempunyai aktivitas fisik yang memang kurang dibanding dengan responden aktivitas fisik yang baik, hal ini didukung dengan penelitian yang dilakukan oleh Danari tentang hubungan aktivitas fisik dengan kejadian obesitas pada anak SD di kota 
Manado yang mempunyai analisis data dengan $(p<0,05)$ yang menunjukkan bahwa terdapat hubungan antara aktivitas fisik dengan obesitas, besarnya pengaruh aktivitas fisik pada obesitas menunjukkan bahwa seseorang yang memiliki aktivitas fisik ringan mempunyai resiko obesitas sebesar 3 kali di banding dengan seseorang yang mempunyai aktivitas berat. Hasil analisis tersebut bersumber dari data aktivitas fisik ringan yang obesitas adalah $85,3 \%$ sedangkan yang tidak obesitas sebesar $14,7 \%$ (Danari, 2013).

Penelitian ini juga sesuai dengan penelitian yang dilakukan Prima dari data yang didapat seseorang yang memiliki aktivitas fisik rendah dan sedang cenderung mengalami obesitas dan sebaliknya seseorang yang mempunyai aktivitas fisik berat cenderung mempunyai tubuh yang ideal yaitu antara tinggi dan berat badan memiliki besar yang seimbang, pada penelitian ini rata-rata responden yang mengalami obesitas mempunyai aktivitas fisik yang rendah dan sedang, sedangkan rata-rata responden yang mempunyai tubuh yang ideal memiliki aktivitas fisik yang berat. Peneliti melakukan analisis data dengan menggunakan uji chi square dengan nilai $p$ 0,000 $(p<0,05)$ maka dapat disimpulkan bahwa aktivitas fisik berpengaruh terhadap obesitas seseorang terlebih tentang tingkatan aktivitas fisik yaitu rendah, sedang dan berat (Prima, Andayani, \& Abdullah, 2018).

\section{Hubungan Pola Makan Dengan Status Obesitas Siswa Laki-Laki Kelas VII SMPN 2 Bantur Kabupaten Malang}

Dari hasil uji statistik di SPSS dengan menggunakan pearson correlation didapat rtabel 0,381 dan rhitung 0,430 dimana rhitung lebih besar dibandingkan dengan rtabel, dengan taraf signifikansi yaitu $0,025 \quad(p<0,05)$ ini menunjukkan ada hubungan yang signifikan antara pola makan dengan status obesitas. Sesuai dengan penelitian yang dilakukan Mokolensang \& Manampiring bahwa adanya hubungan yang bermakna antara obesitas dan pola supan makan seseorang terutama pada pola makan lemak, hal ini juga merupakan efek thermogenesis protein dan karbohidrat lebih tinggi daripada thermogenesis lemak. Subjek sering mengkonsumsi sumber lemak yang berupa minyak goreng dengan besar persentase $32,21 \%$ dari seluruh lemak yang ada. Dari data AKG juga menunjukkan adanya kalori dan lemak yang tinggi pada subjek yang mengalami obesitas di banding dengan yang tidak mengalami obesitas (Mokolensang \& Manampiring, 2016).

Penelitian ini juga sesuai dengan hasil penelitian Mokolensang bahwa pola makan sangat mempengaruhi kejadian obesitas hal ini ditunjukkan dengan adanya hubungan antara obesitas dengan pola makan subjek, makanan yang dikonsusmsi adalah asupan energi, protein, karbohidrat dan lemak dengan hasil $P$ value $(p<0,01)$, penelitian ini kemudian di pertegas dengan adanya hasil analisis regresi logistic bahwa asupan lemak merupakan asupan zat gizi yang paling berpengaruh terhadap kejadian obesitas sedangkan asupan gizi pola makan dalam penelitian ini yaitu, asupan energi, karbohidrat, protein dan lemak dengan $p$ value $(p<0,01)$ (Mokolensang \& Manampiring, 2016). Berdasarkan penyebab-penyebab di atas didapat kesimpulan bahwa seorang obesitas cenderung memiliki pola makan yang kurang baik, dipicu dari faktor eksternal maupun internal, terlebih jika makanan yang dikonsumsi adalah makanan yang mengandung lemak tinggi dan kurang serat, hal itu akan mudah menyebabkan obesitas bagi seseorang. Maka pola makan baik atau asupan gizi yang baik dapat mencegah dari masalah obesitas.

\section{Hubungan Aktivitas Fisik dan Pola Makan Dengan Status Obesitas Siswa Laki-Laki Kelas VII SMPN 2 Bantur Kabupaten Malang}

Dari hasil uji statistik di SPSS dengan menggunakan Korelasi Berganda didapat sig.F Change 0,004 $<0,05$ maka $\mathrm{H}_{0}$ ditolak, dengan nilai $\mathrm{R}$ sebesar 0,607 yang menunjukkan pengaruh yang sedang antara aktivitas fisik dengan pola makan terhadap status obesitas, data tersebut menunjukkan ada hubungan antara aktivitas fisik dan pola makan dengan obesitas. Penelitian ini sesuai dengan penelitian yang dilakukan oleh Tando Prevalensi obesitas pada penelitian pada tokoh agama di Kota Manado adalah 67,34\%. Hasil data yang diperoleh adalah adanya hubungan yang bermakna antara aktivitas fisik terhadap obesitas dengan $p<0,001$ dengan kekuatan hubungan prevalensi $\mathrm{RP}=4,28$, dan terdapat hubungan yang bermakna antara asupan makan dengan obesitas dengan $\mathrm{p}<0,01$.

Dari hasil data tersebut maka hasil penelitian menunjukkan terjadinya obesitas memiliki hubungan yang sangat kuat dengan asupan makan yang mempunyai resiko yaitu tingginya asupan protein, lemak, natrium dan juga rendahnya asupan kalium dan serat dalam tubuh (Tando, 2012). Menurut Restuastuti sebagian besar anak yang mengalami obesitas memiliki asupan energi dan zat gizi makro yang cukup dimana zat gizi makro meliputi karbohidrat, protein dan lemak sedangkan yang non obesitas memiliki asupan energi dan gizi makro yang kurang. Sedangkan anak yang kurang dalam berolahraga memiliki resiko obesitas yang tinggi dan yang 
memiliki kegiatan olahraga yang baik resiko terkena obesitas sangat kecil (Restuastuti, Mailani, \& Ernalia, 2016).

\section{Hubungan Aktivitas Fisik Dengan Status Obesitas Siswa Perempuan Kelas VII SMPN 2 Bantur Kabupaten Malang}

Dari hasil uji statistik di SPSS dengan menggunakan pearson correlation didapat rtabel 0,553 dan rhitung 0,364 dimana rhitung lebih kecil dibandingkan dengan rtabel, dengan taraf signifikansi yaitu $0,222 \quad(p<0,05)$ ini menunjukkan tidak ada hubungan yang signifikan antara aktivitas fisik dengan status obesitas. Penelitian ini sesuai dengan penelitian yang dilakukan oleh Atika yaitu terdapat $68,8 \%$ responden perempuan dan $31,2 \%$ laki-laki, dengan pembagian kategori sesuai variabel yaitu $52 \%$ adalah siswa yang mempunyai aktivitas fisik ringan dan $48 \%$ mempunyai aktivitas fisik sedang dan berat sedangkan persentase tingkat obesitas adalah $55,9 \%$ dan $44,1 \%$ tidak obesitas, hal ini menunjukkan bahwa tidak ada hubungan yang signifikan dari hubungan aktivitas fisik dengan kejadian obesitas siswa SMPN di Pekanbaru (A. M. Sari, Ernalia, \& Bebasari, 2017).

Penelitian yang dilakukan Lariwu menunjukkan adanya hubungan antara aktivitas fisik dengan obesitas dengan $p$ lebih kecil dari $(p<0,05)$, tetapi dalam penelitian ini terdapat faktor lain yang mempengaruhi obesitas yaitu screen time dengan bukti statistik $p$ lebih kecil dari $(p<0,05)$ pada siswa SMP di Kota Tomohon, berbeda dengan aktivitas fisik dan screen time, konsumsi minuman ringan dinyatakan tidak ada hubungan dengan obesitas dibuktikan dengan $p$ lebih besar dari $(p<0,05)$ dan terdapat hubungan antara makanan cepat saji dengan obesitas dengan $p$ lebih kecil dari $(p<0,05)$ (Lariwu, Wariki, \& Nelwan, JeiniRatulangi, 2017). Jadi dapat disimpulkan bahwa obesitas tidak hanya dipengaruhi oleh aktivitas fisik saja tetapi juga dipengaruhi oleh faktor lain yang lebih dominan saat mengalami obesitas.

\section{Hubungan Pola Makan Dengan Status Obesitas Siswa Perempuan Kelas VII SMPN 2 Bantur Kabupaten Malang}

Dari hasil uji statistik di SPSS dengan menggunakan pearson correlation didapat rtabel 0,553 dan rhitung 0,389 dimana rhitung lebih kecil dibandingkan dengan rtabel, dengan taraf signifikansi yaitu $0,189(p<0,05)$ ini menunjukkan tidak ada hubungan yang signifikan antara pola makan dengan status obesitas. Penelitian yang dilakukan Mamarimbing didapat hasil bahwa tidak ada hubungan antara pendidikan dengan obesitas dengan hasil analisis uji Chi-Square nilai $p$ lebih besar dari $\alpha=0,05$, sedangkan faktor lain yang berhubungan dengan obesitas adalah faktor keturunan, didapat hasil uji Chi-Square didapat $p$ lebih kecil dari $\alpha=0,05$ hal ini menunjukkan ada hubungan antara faktor keturunan dengan obesitas. Faktor keturunan merupakan faktor yang berhubungan erat dengan peristiwa obesitas karena gen yang dibawa anak dari ibu. Faktor yang lain adalah pendapatan didapat hasil uji Chi-Square $p$ lebih kecil dari $\alpha=0,05$ hal ini menunjukkan ada hubungan antara pendapatan dengan obesitas (Mamarimbing, Rattu, \& Tumurang, 2016).

Genetik sangat berperan pada terjadinya obesitas, menurut Dewi jika salah satu dari kedua orangtua mengalami obeistas maka anak mempunyai peluang mengalami obesitas sekitar $40 \%$, sedangkan jika kedua orangtua mengalami obesitas semuanya maka kemungkinan peluang mengalami obesitas sekitar $80 \%$. Hal ini juga menyinggung bahwa pria mempunyai peluang lebih besar daripada wanita dalam obesitas karena pria memiliki pola makan yang lebih besar dilihat dari segi frekuensi, jumlah makanan dan jenis makanannya, hal ini juga menjadi faktor pria lebih mudah mengalami obesitas daripada wanita, selain pola makan pria yang merokok juga prediktor kuat dalam kejadian obesitas (Dewi, 2015).

\section{Hubungan Aktivitas Fisik dan Pola Makan Terhadap Status Obesitas Siswa Perempuan Kelas VII SMPN 2 Bantur Kabupaten Malang}

Dari hasil uji statistik di SPSS dengan menggunakan Korelasi Berganda didapat sig.F Change 0,177<0,05 maka $H_{0}$ diterima, dengan nilai $R$ sebesar 0,541 yang menunjukkan pengaruh yang sedang antara aktivitas fisik dengan pola makan terhadap status obesitas, data tersebut menunjukkan tidak ada hubungan yang signifikan antara aktivitas fisik dan pola makan dengan obesitas. Penelitian yang dilakukan oleh Handayani menunjukkan bahwa umur dan jenis kelamin tidak memiliki hubungan dengan obesitas hal ini dibuktikan dengan nilai $p$ lebih besar dari $\alpha=0,05$, pada variabel pengetahuan gizi hasil dari analisis data yaitu terdapat hubungan antara pengetahuan gizi dengan obesitas, pada variabel mengkonsumsi fast food juga beresiko obesitas sebanyak 2,7 kali dengan nilai statistik yaitu sedangkan pada aktivitas fisik beresiko lebih kecil daripada mengkonsumsi fast food yaitu sebesar 2 kali lipat, dari beberapa penjelasan mengenai hubungan 
antar variabel maka Handayani menentukan variabel yang paling dominan pada tingkat hubungan dengan obesitas yaitu pengetahuan gizi dan kebiasaan konsumsi fast food (Handayani, 2018).

Penelitian yang dilakukan oleh Sikalak menyatakan bahwa ada hubungan antara status perkawinan dengan obesitas dengan nilai Chi Square $p$ lebih kecil dari $(p<0,05)$, tetapi tidak terdapat hubungan antara aktivitas fisik dan obesitas dari hasil uji statistik Chi Square menunjukkan nilai $p$ lebih besar $(p<0,05)$, pada variabel kecukupan gizi juga tidak terdapat hubungan antara kecukupan gizi dengan obesitas dengan nilai $p$ lebih besar dari $(p<0,05)$, sedangkan pada faktor lain terdapat hubungan antara keturunan dengan obesitas dibuktikan dengan nilai Chi Square $p$ lebih kecil dari $(p<0,05)$. Maka dapat disimpulkan bahwa obesitas dipengaruhi oleh beberapa hal, karena sifat hubungannya ada yang dominan dan tidak dominan, faktor dominan merupakan faktor yang berperan besar pada seseorang yang mengalami obesitas, sedangkan faktor tidak dominan merupakan faktor yang berperan sedikit atau kecil pada seseorang yang mengalami obesitas. Pada individu yang berbeda akan berbeda pula faktor dominan yang terjadi pada individu tersebut karena lingkungan, status sosial, gen dan pendidikan yang berbeda (Sikalak, Widajanti, \& Aruben, 2017).

\section{KESIMPULAN}

Berdasarkan paparan data hasil penelitian dan pembahasan di atas, maka penelitian ini dapat disimpulkan, (1) Ada hubungan antara aktivitas fisik dengan status obesitas pada siswa laki-laki kelas VII SMPN 2 Bantur, (2) Tidak ada hubungan antara aktivitas fisik dengan status obesitas pada siswa perempuan kelas VII SMPN 2 Bantur, (3) Ada hubungan antara pola makan dengan status obesitas pada siswa laki-laki kelas VII SMPN 2 Bantur, (4) Tidak ada hubungan antara pola makan dengan status obesitas pada siswa perempuan kelas VII SMPN 2 Bantur, (5) Ada hubungan antara aktivitas fisik dan pola makan dengan status obesitas pada siswa laki-laki kelas VII SMPN 2 Bantur, (6) Tidak ada hubungan antara aktivitas fisik dan pola makan dengan status obesitas pada siswa perempuan kelas VII SMPN 2 Bantur.

\section{Ucapan Terima Kasih}

Dalam penyusunan artikel ini tentunya tidak berjalan dengan mulus, terdapat beberapa kesulitan dan hambatan dalam penyusunannya mulai dari awal sampai akhir. Namun hambatan dan kesulitan dapat terlewati karena adanya bimbingan, kerjasama dan bantuan dari beberapa pihak yang membantu dalam menghadapi kesulitan dalam penyusunan artikel ini. Peneliti mengucapkan terima kasih yang sebesarbesarnya kepada: Dr. Sapto Adi, M.Kes selaku Dekan Fakultas IImu Keolahragaan Universitas Negeri Malang yang telah memberikan kesempatan kepada peneliti untuk mengikuti perkuliahan di Fakultas IImu Keolahragaan Universitas Negeri Malang, Dr. dr. Moch. Yunus, M.Kes selaku Wakil Dekan I Fakultas IImu Keolahragaan yang telah memberikan izin kepada peneliti untuk melakukan penelitian, Dr. Lokananta Teguh Hari Wiguna, M.Kes selaku Ketua Jurusan Pendidikan Jasmani dan Kesehatan Fakultas IImu Keolahragaan atas petunjuk dan nasehatnya terhadap peneliti, Prof. Dr. M.E Winarno, M.Pd selaku dosen pembimbing yang telah sabar memberikan bimbingan, arahan dan dorongan kepada peneliti hingga peneliti dapat menyelesaikan skripsi dengan tepat waktu, Bu Anis selaku guru Pendidikan Jasmani di SMPN 2 Bantur yang telah membantu dalam proses penelitian.

\section{DAFTAR PUSTAKA}

Ayu, R., \& Sartika, D. (2011). Faktor Faktor Risiko pada Anak 5-15 Tahun di Indonesia. Makara, Kesehatan, 15(1), 37-43. https://doi.org/10.1371/journal.pone.0039007

Danari, A. L. (2013). Hubungan Aktivitas Fisik Dengan Kejadian Oobesitas Pada Anak SD di Kota Manado. Hubungan Aktivitas Fisik Dengan Kejadian Obesitas Pada Anak Sd Di Kota Manado, 1, 4-7.

Dewi, M. C. (2015). Faktor-Faktor yang Menyebabkan Obesitas pada Anak. Majority.

Dinas Kesehatan Republik Indonesia. (2013). Riset Kesehatan Dasar. Obesitas, 87-90. https://doi.org/1 Desember 2013

Handayani, D. R. (2018). Faktor dominan obesitas pada siswa sekolah menengah atas di Tangerang Selatan 
Indonesia determinant of obesity among senior high school student at south Tangerang Indonesia. Jurnal Kedokteran Dan Kesehatan, 1-10.

Hikmawati, \& Mas'ud. (2015). Standar Fisik Ideal dalam Perspektif Budaya dan Kesehatan (Kasus: Obesitas Pada Etnis Bugis) Hikmawati Mas'ud 1 Jurusan Gizi Politeknik kesehatan Makassar. 25-33.

Lariwu, C. K., Wariki, W., \& Nelwan, JeiniRatulangi, S. (2017). Faktor-Faktor Risiko Yang Berhubungan Dengan Kejadian Obesitas Pada Siswa SMP di Kota Tomohon. 13-23.

Mamarimbing, S., Rattu, J. A. ., \& Tumurang, M. N. (2016). Faktor-Faktor yang Berhubungan dengan Kejadian Obesitas pada Wanita Usia Produktif di Wilayah Kerja Puskesmas Tinoor Tomohon Utara. EJournal Health, (2013), 140-152. https://doi.org/10.1007/s10761-010-0128-4

Mokolensang, O. G., \& Manampiring, A. E. F. (2016). Hubungan Pola Makan Dan Obesitas Pada Remaja Di Kota Bitung. Jurnal E-Biomedik, 4(1). https://doi.org/10.35790/ebm.4.1.2016.10848

Pramono, A. (2014). Kontribusi Makanan Janan dan Aktifitas Fisik Terhadap Kejadian Obesitas pada Remaja di Kota Semarang. Gizi Indonesia, 2, 129-136.

Prima, T. A., Andayani, H., \& Abdullah, M. N. (2018). Hubungan Konsumsi Junk Food Dan Aktivitas Fisik Terhadap Obesitas Remaja Di Banda Aceh. Jurnal IImiah Mahasiswa Kedokteran Medis, 4(1), $20-27$.

Restuastuti, T., Mailani, J., \& Ernalia, Y. (2016). Jihadimailanigmail.Com. 3(I).

Riset Kesehatan Republik Indonesia. (2013). Penyajian Pokok-Pokok Hasil Riset Kesehatan Dasar 2013.

Rumajar, R. \& B. (2015). Faktor-faktor yang Mempengaruhi Obesitas pada Anak TK Providensia Manado. EJournal Kperawatan, 3, 1-8.

Sari, A. M., Ernalia, Y., \& Bebasari, E. (2017). Hubungan Aktivitas Fisik dengan Kejadian Obesitas pada Siswa SMPN di Pekanbaru. Jurnal Online Mahasiswa Fakultas Kedokteran Universitas Riau, 4(1), 1-8.

Sari, E. (2013). Buku Saku Nutrisi. Jakarta: EGC.

Sikalak, W., Widajanti, L., \& Aruben, R. (2017). Faktor-Faktor Yang Berhubungan Dengan Kejadian Obesitas Pada Karyawati Perusahaan Di Bidang Telekomunikasi Jakarta Tahun 2017. Jurnal Kesehatan Masyarakat (e-Journal), 5(3), 193-201.

Sofa, I. M. (2018). Kejadian Obesitas, Obesitas Sentral, dan Kelebihan Lemak Viseral pada Lansia Wanita The Incidence of Obesity, Central Obesity, and Excessive Visceral Fat among Elderly Women. Amerta Nutr. https://doi.org/10.20473/amnt.V2.i3.2018.228-236

Tando, V. T. H. N. M. (2012). Pada Tokoh Agama Di Kota Manado. 4(1), 289-298. 